\title{
Functioning in Women with Cervical Cancer in Brazil: the Perspective of Experts
}

\section{Funcionalidade em mulheres com câncer do colo do útero no Brasil: perspectiva dos especialistas}

\author{
Luciana Castaneda ${ }^{1}$ Anke Bergmann ${ }^{2}$ Shamyr Castro ${ }^{3}$ Rosalina Koifman ${ }^{4}$ \\ ${ }^{1}$ Instituto Federal de Educação Ciência e Tecnologia, Rio de Janeiro, \\ RJ, Brazil \\ 2 Instituto Nacional de Câncer, Rio de Janeiro, RJ, Brazil \\ 3 Universidade Federal do Ceara, Fortaleza, CE, Brazil

\begin{abstract}
Address for correspondence Luciana Castaneda, Rua Professor Carlos Wenceslau, 343, 21715-000, Realengo, Rio de Janeiro, RJ, Brazil (e-mail: lucianacastaneda@yahoo.com.br).
\end{abstract}

${ }^{4}$ Fundação Oswaldo Cruz, Rio de Janeiro, RJ, Brazil

Rev Bras Ginecol Obstet 2018;40:260-265.

\begin{abstract}
Keywords

- health personnel

- international classification of functioning

- disability and health

- medical oncology

- uterine cervical neoplasms
\end{abstract}

\section{Resumo}

Objective The objective of this study was to identify the perspective of the specialists about functioning in women with cervical cancer (CC).

Methods A study was conducted with specialists using the Delphi methodology. The specialist contacts were found in oncology organizations and associations, as well as in a referral hospital in the treatment of CC. The questions that the experts answered covered the biopsychosocial domains of the International Classification of Functioning, Disability and Health (ICF).

Results Twenty-five specialists participated in the study. The experts' responses generated 485 significant concepts. The categories that presented the highest frequencies of reporting by the specialists were health services, systems and policies; structure of the reproductive system; health professionals and sexual function.

Conclusion Regarding the perception of the specialists, this study concluded that 24 categories of ICF are the most relevant in the context of functioning in women with CC. The results suggest that the biopsychosocial perspective was incorporated in the experts' perceptions about the functioning phenomenon in women with CC in Brazil.

Objetivo O objetivo deste estudo foi identificar a perspectiva dos especialistas sobre o contexto da funcionalidade em mulheres com câncer do colo do útero (CCU).

Métodos foi realizado um estudo com especialistas utilizando a metodologia Delphi. As informações para contatar os especialistas foram obtidas em organizações e associações de oncologia, assim como em um hospital de referência no tratamento do CCU. As perguntas que os especialistas responderam abrangeram os domínios biopsicossociais da Classificação Internacional de Funcionalidade, Incapacidade e Saúde (CIF). received

October 25, 2017

accepted

January 24, 2018

published online

May 9, 2018
DOI https://doi.org/

10.1055/s-0038-1646921. ISSN 0100-7203.
Copyright (e) 2018 by Thieme Revinter

Publicações Ltda, Rio de Janeiro, Brazil

License terms

ㄷ) (i) $\ominus$ (\$) 

Palavras-chave
- pessoal de saúde
- classificação internacional de funcionalidade
- incapacidade e saúde
- oncologia
- neoplasias do colo do útero

Resultados Participaram do estudo 25 especialistas. As respostas dos especialistas geraram 485 conceitos significativos. As categorias que apresentaram as maiores frequências de relato pelos especialistas foram os serviços, sistemas e políticas de saúde; estrutura do sistema reprodutivo; profissionais de saúde e função sexual.

Conclusão quanto à percepção de especialistas, este estudo concluiu que 24 categorias da CIF são as mais relevantes no contexto da funcionalidade em mulheres com CCU. Os resultados sugerem que a perspectiva biopsicossocial foi incorporada na percepção que os especialistas têm sobre o fenômeno da funcionalidade em mulheres com CCU no Brasil.

\section{Introduction}

Although cervical cancer (CC) is a highly preventable disease, it remains a major public health problem. ${ }^{1}$ It is the third most common type of cancer among women around the world. ${ }^{2}$ More than $85 \%$ of the global burden and $88 \%$ of global mortality due to CC occur in developing countries. In Brazil, $\mathrm{CC}$ is the second most common cancer among women, ${ }^{3}$ and in a research with a sample of 37,638 Brazilian women, the diagnosis of CC in late clinical stages was observed in $70.6 \%$ of cases. In the same study, CC was associated with a presence of squamous cell carcinoma (odds ratio $[\mathrm{OR}]=1.8 ; 95 \%$ confidence interval $[\mathrm{CI}] 1.7-2.0)$, age $\geq 50$ years $(\mathrm{OR}=1.5 ; 95 \% \mathrm{CI}$ 1.4-1.6), living with a partner ( $\mathrm{OR}=1.3$; $95 \% \mathrm{CI} 1.2-1.4)$, black skin color ( $\mathrm{OR}=1.2 ; 95 \% \mathrm{CI} 1.1-1.4)$, and low educational level $(\mathrm{OR}=1.2 ; 95 \% \mathrm{CI} 1.1-1.3){ }^{4}$

The treatment and pathophysiology of CC can lead to negative effects on the quality of life of women with CC. The consequences can lead to negative effects in women's selfidentity, body image, intimate relationships, and perception as a mother and a partner. ${ }^{5}$

In the current scenario of oncological rehabilitation, it is increasingly important to demonstrate the effectiveness of the treatment with outcome measures. The planning of interventions for cancer patients should be accompanied by key indicators for rehabilitation outcomes, such as quality of life, well-being, and functioning. ${ }^{6}$ The information generated by indicators of functioning can be used by different professionals in a multidisciplinary cancer rehabilitation team. The rehabilitation cycle involves the identification of the patients' problems and needs and their relationship to key factors that could be potential target points for interventions. Subsequently, the intervention goals are set, the interventions are planned and conducted, and their effects on the patients' health and functioning are being evaluated. ${ }^{7}$

The International Classification of Functioning, Disability and Health (ICF) provides a common language for describing functioning. The ICF aims to provide a universal language for health and health-related professionals. The ICF model conceptualizes functioning as the interplay between the components body functions and body structures, activities and participation, and contextual factors (that is, environmental and personal factors). The ICF's alphanumerical classification system is organized within a nested hierarchical structure with four levels. Therefore, a lower category shares the higherlevel category of which it is a member; in other words., the use of a lower level (more detailed) category automatically implies the higher-level category is applicable but not the other way around. ${ }^{8}$ The ICF's classification offers a comprehensive spectrum of categories to describe these components.

Cervical cancer is a significant public health problem, and until now, there has been no proposal for a disease-related ICF application. The purpose of this study was to identify the perceptions of experts regarding the aspects of functioning in women with CC using the ICF as a reference tool.

\section{Methods}

\section{Study Design}

We conducted a Delphi study with experts. The methodology was adapted from the proposal by Selb et al $(2015)^{9}$. The participants were identified and recruited using information about cancer-related associations and societies in Brazil. The following entities were contacted: the Brazilian Association of Cancer Therapy, the Brazilian Society of Oncologic Nursing and the Brazilian Society of Psycho-Oncology. In addition to the societies and associations, we identified professionals with experience in gynecologic oncology at a CC referral treatment hospital in Rio de Janeiro. The present research was approved by the Research Ethics Committee of the National Cancer Institute

\section{Subjects}

For the development of this research, the entities and the referral hospital sectors were contacted, and the objectives of the survey were explained. We included all professionals registered in selected associations and all the professionals appointed by the referral hospital experts. The data were collected between March and April 2016. The experts who responded were invited to participate through the SurveyMonkey platform (SurveyMonkey, San Mateo, CA, USA) and composed a committee of experts. 


\section{Materials}

The script of the interview consisted of a questionnaire with sociodemographic variables, professional information, and open-ended questions about aspects from different functioning areas (-Table $\mathbf{1}$ ). The following variables were collected: age, gender, professional training, and highest earned degree, professional experience in oncology and expertise area. The open-ended questions asked for relevant aspects of functioning pertaining to the different areas (or components) of the ICF (for example, body functions). The participants had three weeks to answer. Every seven days, a reminder was sent to the specialist's electronic contact. The experts who participated in the study had no knowledge of the other participants.

\section{Procedures}

The categories listed by the experts in the five open-ended questions were linked to the ICF via a previously established methodology of ICF linking rules. The concepts contained in the items proposed by the experts were linked to a more specific category as per the linking rules proposed by Cieza et al (2016). ${ }^{10}$ These rules were developed based on experience accumulated during the process of linking hundreds of clinical measurement documents and health statuses with ICF. ${ }^{11}$ This step was performed by two independent researchers with experience in this methodology.

If a concept could not be assigned to ICF, it was defined as "not covered." Answers that contained information related to health conditions (such as comorbidities) were coded as "hc (health condition)." The concepts that were covered by ICF (including personal factors) but could not be assigned to one specific category was classified as "not definable." This step was performed by two independent coders with expertise in this methodology.

In the case of disagreement between the two coders, there was a second round of evaluation by each reviewer. The degree of agreement between the two professionals was calculated by kappa coefficient with a 95\% CI. The kappa coefficient found was $0.72(0.63-0.81)$.

Relative frequencies of ICF categories were calculated. Categories were aggregated to the second hierarchical level. Therefore, third- and fourth-level categories were presented at the corresponding ICF second level. Data analysis was performed using the measures of central tendency and dispersion for continuous variables and frequency distribution for categorical variables.

\section{Results}

One hundred and twenty experts were invited, and 26 responded. About $85 \%$ of the experts were female. More than $60 \%$ reported having a postgraduate degree, and more than half worked in the clinical area. The average age of the participants was 38 years (-Table 2 ).

The experts' answers generated 485 significant concepts. After the process of linking concepts with ICF language and codes, it was possible to establish a connection with 400 specific categories. Of these, 85 contents could not be linked to ICF specific category, for example, concepts such as educational level, adherence to treatment and knowledge about the concept of health.

About these 400 specific categories, 36\% of the concepts referred to body functions, $25.7 \%$ to body structures, $13.5 \%$ to activities and participation and $24.7 \%$ to environmental factors. To propose a set of the most prevalent categories considered relevant to specialists, - Table 3 presents the specific ICF categories that had a prevalence $\geq 5 \%$. Six (23.1\%) categories refer to body functions, five (19.2\%) to body structures, eight (30.7\%) to activity and participation, five $(19.2 \%)$ to environmental factors-facilitators, and two (7\%) to environmental factors and barriers. The most frequently presented categories were services, health systems, and policies; structure of the reproductive system; health professionals; sexual function; and immediate family.

\section{Discussion}

This is the first research to explore aspects of functioning in women with CC through an approach from the perspective of experts involved in CC treatment. In relation to results found for body functions, the category that showed the highest frequency was sexual functions (21\%). Some studies indicate that sexual function can be seriously affected because of deleterious effects of cancer treatment, especially radiation, which can lead to difficulties for a woman and her partner. ${ }^{12,13}$

Table 1 Questions asked and their International Classification of Functioning, Disability and Health component

\begin{tabular}{|l|l|}
\hline Asked of the experts & Component of the ICF \\
\hline $\begin{array}{l}\text { If you think about the body and mind of women with cervical cancer, } \\
\text { what problems are relevant to people with this condition? }\end{array}$ & Body functions \\
\hline $\begin{array}{l}\text { If you think about the body of women with cervical cancer, } \\
\text { in which parts are the problems? }\end{array}$ & Body structures \\
\hline $\begin{array}{l}\text { If you think about the everyday life of women with cervical cancer, } \\
\text { what are their problems? }\end{array}$ & Activities and participation \\
\hline $\begin{array}{l}\text { If you think about the environment and the living conditions of } \\
\text { women with cervical cancer, what could be considered as a support? }\end{array}$ & Environmental factors-facilitators \\
\hline $\begin{array}{l}\text { If you think about the environment and the living conditions of } \\
\text { women with cervical cancer, which could be considered as a barrier? }\end{array}$ & Environmental factors-barriers \\
\hline
\end{tabular}

Abbreviation: ICF, International Classification of Functioning, Disability and Health. 
Table 2 Sociodemographic data of the experts participating in the Delphi survey $(n=25)$

\begin{tabular}{|l|l|l|}
\hline \multicolumn{2}{|l|}{$N$ (\%) } & \\
\hline Sex & \multicolumn{2}{l|}{} \\
\hline Female & $21(84)$ & \\
\hline Male & $4(16)$ & \\
\hline Higher degree & $16(64)$ & \\
\hline Lato-Sensu & $6(24)$ & \\
\hline Master's degree & $3(12)$ & \\
\hline PhD & \multicolumn{3}{|l|}{} \\
\hline Area of practice & $14(56)$ & \\
\hline Clinic & $3(12)$ & \\
\hline Research & $5(20)$ & Median \\
\hline Management & $3(12)$ & 37 \\
\hline Teaching & $\begin{array}{l}\text { Mean } \\
\text { (standard deviation) }\end{array}$ & 14 \\
\hline & $38.0(5.6)$ & 10 \\
\hline $\begin{array}{l}\text { Age } \\
\text { oncoginecology area }\end{array}$ & $14.4(5.4)$ & \\
\hline Time to degree & $10.3(5.6)$ & \\
\hline Time of experience in & \\
\hline
\end{tabular}

Factors such as loss of interest in sex, pain associated with intercourse and worsening of sex life were singled out as prognostic factors of sexual dysfunction in women who had undergone treatment for $\mathrm{CC} .{ }^{14}$ The body structures most often cited by experts were structures of the reproductive system (s630). The treatment modalities available, namely, hysterectomy, radiotherapy and brachytherapy combined with chemotherapy that are invariably associated with the problems of early menopause justify this finding reported by experts. According to Teh et al (2014), ${ }^{14}$ loss of fertility is a key issue for young survivors of CC. In addition, reduced fecundity and an increased possibility of adverse outcomes in pregnancy are relevant aspects of women's reproductive issues. There was also a higher frequency of losses in the emotional functions (b152). This has also been found in other studies. Kim et al $(2010)^{15}$ found that the overall prevalence rate of distress with gynecological cancers was $29.6 \%$. Jensen et al (2017), ${ }^{16}$ in a study using patient-reported outcomes measurement information, found a prevalence greater than $50 \%$ for symptoms of anxiety and depression in women with CC. The higher prevalence of body functions and body structures found in our study point to the experts' biological perception of functioning, as they persist in insisting on a biological approach. It is not about being new, it is about being a model that no longer responds to the needs in cancer care. Our results reaffirm the imminent need for a tool with a biopsychosocial approach. Information on functioning is essential for planning effective strategies for CC care.

Regarding activity and participation, family relations (d760) and recreation and leisure (d920) were the most
Table 3 International Classification of Functioning, Disability and Health categories identified by at least $5 \%$ of the health professionals

\begin{tabular}{|c|c|c|}
\hline ICF Category & Description & $\%^{*}$ \\
\hline \multicolumn{3}{|l|}{ Body functions } \\
\hline b152 & Emotional functions & 16.7 \\
\hline b280 & Sensation of pain & 8.4 \\
\hline b435 & Immunological system functions & 9.1 \\
\hline b620 & Urination functions & 10.5 \\
\hline b640 & Sexual functions & 21 \\
\hline b660 & Procreation functions & 7 \\
\hline \multicolumn{3}{|c|}{ Body structures } \\
\hline s540 & Structure of the intestine & 12.6 \\
\hline s610 & Structure of the urinary system & 14.6 \\
\hline s620 & Structure of the pelvic floor & 7.8 \\
\hline s630 & $\begin{array}{l}\text { Structure of the } \\
\text { reproductive system }\end{array}$ & 47.6 \\
\hline s750 & Structure of the lower extremity & 8.7 \\
\hline \multicolumn{3}{|c|}{ Activity and participation } \\
\hline $\mathrm{d} 450$ & Walking & 5.6 \\
\hline d570 & Looking after one's health & 7.4 \\
\hline d760 & Family relationships & 11.1 \\
\hline $\mathrm{d} 770$ & Intimate relationships & 9.3 \\
\hline d845 & $\begin{array}{l}\text { Acquiring, keeping, } \\
\text { and terminating a job }\end{array}$ & 5.6 \\
\hline $\mathrm{d} 850$ & Remunerative employment & 9.3 \\
\hline d910 & Community life & 5.6 \\
\hline d920 & Recreation and leisure & 11.1 \\
\hline \multicolumn{3}{|c|}{ Environmental factors-facilitators } \\
\hline e310 & Immediate family & 20.7 \\
\hline e315 & Extended family & 7 \\
\hline e355 & Health professionals & 25.9 \\
\hline e530 & $\begin{array}{l}\text { Utilities services, } \\
\text { systems, and policies }\end{array}$ & 5.2 \\
\hline e580 & $\begin{array}{l}\text { Health services, } \\
\text { systems, and policies }\end{array}$ & 8.6 \\
\hline \multicolumn{3}{|c|}{ Environmental factors/barriers } \\
\hline e315 & Extended family & 12.2 \\
\hline e580 & $\begin{array}{l}\text { Health services, } \\
\text { systems, and policies }\end{array}$ & 51.2 \\
\hline
\end{tabular}

Abbreviation: ICF, International Classification of Functioning, Disability and Health.

* percentage of experts who reported the ICF category.

cited by the expert committee. In a qualitative study on questions of subjectivity, gender, family, and health services, Villafuerte et al (2007) ${ }^{17}$ pointed out that cancer may be an event that women almost always experience alone. They rarely share their experience with their family because of poor communication with their emotional and social 
support network or because they want to protect their children from pain. Before this experience, women recognized a greater desire for moral support from their partners, mostly on their own, but sometimes their response was abandonment. The high frequency of the category recreation and leisure can be related to a lower level of recreational activities in women with CC, who often experience depression as a comorbidity. In a study that assessed the quality of life in patients with CC, Pfaendler et al $(2015)^{18}$ found that $25 \%$ of the women interviewed reported decreased social and leisure activities.

Environmental factors were analyzed separately as facilitators and barriers. The highest relative frequency found for a facilitator was Support from Health Professionals (e355). This finding may reflect how experts see their own responsibility in the therapeutic process. In a national professional practice telephone survey in the context of CC, Stormo et al $(2014)^{19}$ concluded that professionals play a key role in increasing therapist-patient communication and in access to services related to CC. Paradoxically, the barrier of environmental factors that had the highest frequency was services, health systems and policies (e580), with a frequency higher than $50 \%$. In an analysis of chronic non-communicable diseases in Brazil, Barreto et al $(2011)^{20}$ reported that the five-year survival for patients with breast, prostate and lung cancers in two Brazilian cities was lower than that of highincome countries, suggesting difficulties or unequal access to diagnostic procedures and treatment in Brazil. This finding is consistent with the premise that the survival and prognosis of a curable cancer are intimate and positively related to the income of the country. The high frequency of category e580 may reflect a certain degree of frustration and overload related to access to care for patients with $\mathrm{CC}$ under public assistance services. Despite improvements in the coverage of cytological examinations in Brazil, this is still considered insufficient to reduce mortality by CC in the country. Advanced staging at diagnosis may be a factor that interferes directly in the prognosis and functioning. A late diagnosis makes access to health services difficult and reveals the quantitative and qualitative lack of oncological health services. Universal access was guaranteed constitutionally through social conquest of a universal health system. ${ }^{21}$ However, only the formal barriers are down. Difficulties in access and continuity of health care remain in Brazil and configure the perverse trait in public health policies in the country. $^{22}$

The personal factors (PFs) component with the other ICF components covers complex interactions that constitute functioning and disability. However, in contrast with the other components of the framework, PFs are not implemented by an according taxonomy and classification system. The PFs found in our study, such as adhesion to treatment, motivation and educational level, are examples of fundamental information in the field of functioning outcome measures that are not currently classified by the ICF. In a revision, Müller and Geyh $(2015)^{23}$ identified a common core of content issues for a potential ICF PFs classification. They pointed out that this can contribute to future classification development activities in relation to PFs.
The list of ICF categories generated by specialist opinions can serve as a template for the data documentation of functioning in women with CC. The use of the biopsychosocial approach can provide a starting point for the development of therapeutic goals and can help health professionals involved in cancer rehabilitation to define the responsibility of each.

In the context of oncology, in another study that used a methodology similar to that used in this work, Tschiesner et al $(2010)^{24}$ concluded that professionals with experience in the treatment of head and neck tumors tend more often to report content relating to body functions and structures. In a study that evaluated the perceptions of experts in relation to breast cancer, Brach et al $(2004)^{25}$ had similar results. Our results point to a convergence in relation to these studies.

The possible limitations of the study are: sub-sample of gynecologic oncology experts (therefore, we do not suggest generalization of the results); high non-response rate; professionals with greater awareness of the impact of the disease would be more motivated to respond; the majority of respondents were women (who may have a greater view on women functioning); a distribution of participants by region was not made (experts who reside in more developed regions and with greater access to health services can have a different view of functioning compared with professionals from less developed regions of the country). Regarding the sub-sample, our sample size did not differ much from other expert opinion studies that have used a similar approach. ${ }^{26-28}$ Our first suggestion is that this issue should be carefully addressed in other countries with different health care systems. Another limitation is the lack of discussion about the concept of quality of life in oncology. The differentiation between quality of life, well-being and functioning is not very well explored in our study. So, our second suggestion is that future studies go deeper into the topic so that they may contribute to a better semantic understanding of these new health indicators.

\section{Conclusion}

Our results suggest that 24 ICF categories were considered the most relevant to experts. Of these 24 categories, a heterogeneous profile was observed in the the domains that affected CC functioning. This may reflect greater dissemination regarding the biopsychosocial approach in oncological care. Considering the preliminary character of the study, additional research applying larger samples and comparing results with those of experts from other regions and countries can provide a greater range of information about the experts' perceptions.

\section{Contributions}

Castaneda L., Bergmann A., Castro S. and Koifman R. contributed with project and interpretation of data, writing of the article, critical review of the intellectual content and final approval of the version to be published.

\section{Conflicts of Interest}

The authors declare that there are no conflicts of interest. 


\section{References}

1 Pierce Campbell CM, Curado MP, Harlow SD, Soliman AS. Variation of cervical cancer incidence in Latin America and the Caribbean. Rev Panam Salud Publica 2012;31(06):492-498

2 Ferlay J, Shin HR, Bray F, Forman D, Mathers C, Parkin DM. Estimates of worldwide burden of cancer in 2008: GLOBOCAN 2008. Int J Cancer 2010;127(12):2893-291710.1002/ijc.25516

3 da Fonseca AJ, Ferreira LP, Dalla-Benetta AC, Roldan CN, Ferreira ML. [Epidemiology and economic impact of cervical cancer in Roraima, a Northern state of Brazil: the public health system perspective]. Rev Bras Ginecol Obstet 2010;32(08):386-392

4 Thuler LC, de Aguiar SS, Bergmann A. [Determinants of late stage diagnosis of cervical cancer in Brazil]. Rev Bras Ginecol Obstet 2014;36(06):237-24310.1590/S0100-720320140005010

5 Ferrandina G, Mantegna G, Petrillo M, et al. Quality of life and emotional distress in early stage and locally advanced cervical cancer patients: a prospective, longitudinal study. Gynecol Oncol 2012;124(03):389-39410.1016/j.ygyno.2011.09.041

6 Gilchrist LS, Galantino ML, Wampler M, Marchese VG, Morris GS, Ness KK. A framework for assessment in oncology rehabilitation. Phys Ther 2009;89(03):286-30610.2522/ptj.20070309

7 Rauch A, Cieza A, Stucki G. How to apply the International Classification of Functioning, Disability and Health (ICF) for rehabilitation management in clinical practice. Eur J Phys Rehabil Med 2008;44(03):329-342

8 World Health Organization. The International Classification of Functioning, Disability and Health. Geneva: WHO; 2001

9 Selb M, Escorpizo R, Kostanjsek N, Stucki G, Üstün B, Cieza A. A guide on how to develop an International Classification of Functioning, Disability and Health Core Set. Eur J Phys Rehabil Med 2015;51(01):105-117

10 Cieza A, Fayed N, Bickenbach J, Prodinger B. Refinements of the ICF Linking Rules to strengthen their potential for establishing comparability of health information. Disabil Rehabil 2016; 17:1-1010.3109/09638288.2016.1145258

11 Castaneda L, Castro SS, Bahia L. Construtos de incapacidade presentes na Pesquisa Nacional por Amostra de Domicílio (PNAD): uma análise baseada na Classificação Internacional de Funcionalidade, Incapacidade e Saúde (CIF). Rev Bras Estud Popul 2014;31:419-42910.1590/S0102-30982014000200009

12 Ye S, Yang J, Cao D, Lang J, Shen K. A systematic review of quality of life and sexual function of patients with cervical cancer after treatment. Int J Gynecol Cancer 2014;24(07):1146-115710.1097/ IGC.0000000000000207

13 Ljuca D, Marošević G. Impact of chemoradiotherapy on vaginal and sexual function of patients with FIGO IIb cervical cancer. Bosn J Basic Med Sci 2011;11(01):62-6410.17305/bjbms.2011.2628

14 Teh WT, Stern C, Chander S, Hickey M. The impact of uterine radiation on subsequent fertility and pregnancy outcomes. BioMed Res Int 2014;2014:482968 10.1155/2014/482968
15 Kim SH, Kang S, Kim YM, et al. Prevalence and predictors of anxiety and depression among cervical cancer survivors in Korea. Int J Gynecol Cancer 2010;20(06):1017-102410.1111/IGC.0b013e3181e4a704

16 Jensen RE, Potosky AL, Moinpour CM, et al. United States population-based estimates of patient-reported outcomes measurement information system symptom and functional status reference values for individuals with cancer. J Clin Oncol 2017;35(17): 1913-192010.1200/JCO.2016.71.4410

17 Villafuerte BE, Gómez LL, Betancourt AM, Cervantes ML. Cervical cancer: a qualitative study on subjectivity, family, gender and health services. Reprod Health 2007;4:2 10.1186/1742-4755-4-2

18 Pfaendler KS, Wenzel L, Mechanic MB, Penner KR. Cervical cancer survivorship: long-term quality of life and social support. Clin Ther 2015;37(01):39-4810.1016/j.clinthera.2014.11.013

19 Stormo AR, de Moura L, Saraiya M. Cervical cancer-related knowledge, attitudes, and practices of health professionals working in brazil's network of primary care units. Oncologist 2014;19(04): 375-38210.1634/theoncologist.2013-0318

20 Barreto ML, Teixeira MG, Bastos FI, Ximenes RA, Barata RB, Rodrigues LC. Successes and failures in the control of infectious diseases in Brazil: social and environmental context, policies, interventions, and research needs. Lancet 2011;377(9780):1877-188910.1016/S0140-6736(11)60202-X

21 Brito-Silva K, Bezerra AFB, Chaves LDP, Tanaka OY. Integrality in cervical cancer care: evaluation of access. Rev Saude Publica 2014; 48(02):240-24810.1590/S0034-8910.2014048004852

22 Paim J, Travassos C, Almeida C, Bahia L, Macinko J. The Brazilian health system: history, advances, and challenges. Lancet 2011; 377(9779):1778-179710.1016/S0140-6736(11)60054-8

23 Müller R, Geyh S. Lessons learned from different approaches towards classifying personal factors. Disabil Rehabil 2015;37 (05):430-43810.3109/09638288.2014.923527

24 Tschiesner U, Becker S, Cieza A. Health professional perspective on disability in head and neck cancer. Arch Otolaryngol Head Neck Surg 2010;136(06):576-58310.1001/archoto.2010.78

25 Brach M, Cieza A, Stucki G, et al. ICF Core Sets for breast cancer.J Rehabil Med 2004;36(44, Suppl)121-12710.1080/16501960410016811

26 van de Ven-Stevens LA, Graff MJ, Selles RW, et al. Instruments for assessment of impairments and activity limitations in patients with hand conditions: A European Delphi study. J Rehabil Med 2015;47(10):948-95610.2340/16501977-2015

27 Engelbarts M, Schuster V, Kisser U, et al. The "Comprehensive ICF Core Set for Head and Neck Cancer": a Delphi consensus survey among German speaking speech and language therapists. Eur Arch Otorhinolaryngol 2017;274(06):2589-259910.1007/s00405-0174494-y

28 Renom M, Conrad A, Bascuñana H, et al. Content validity of the Comprehensive ICF Core Set for multiple sclerosis from the perspective of speech and language therapists. Int J Lang Commun Disord 2014;49(06):672-68610.1111/1460-6984.12086 